\title{
The Purchase of Agricultural Land a Well Thought out Process in the Agribusiness Enterprises
}

\author{
$\mathrm{PhD}$ candidate Milen Vlaev \\ University of Economics - Varna, Varna, Bulgaria \\ milen.vlaev@ue-varna.bg
}

\begin{abstract}
The changing economic environment has and will continue to have an impact on the price of agricultural land and lease. It is the possession of this main asset for production (agricultural land) that is becoming increasingly important for the processes in the Agribusiness enterprises. The purpose of the article is to explore and present possible models for assessing the need to own agricultural land and how this asset affects the processes in the Agribusiness enterprises. The results focus on the need to identify and build a proper strategy in the Agribusiness enterprises, trends and processes in the pricing of land properties. The subject of the study is the determinants leading to changes in the prices of the agricultural land and lease, and their impact on the processes in the Agribusiness enterprises. The survey covers processes related to price dynamics, both at national level and external effects, determining trends in the country.
\end{abstract}

Keywords: agricultural land, lease, financing, balance sheet structure, interest rate, land price

JEL Code: Q10 DOI: https://doi.org/10.36997/IJUSV-ESS/2020.9.3.40

1. Agricultural land as an asset of crucial importance to the Agribusiness enterprises.

Agricultural land and the rights to it have historically been at the heart of a number of reforms in human history. Some of them have been intense with turbulent processes, revolutions and wars, while others have been extensive with changes in the legislative framework, through economic processes such as urbanization, changing relations more slowly over time. In both cases, however, the ownership of agricultural land and its transition from one economic stratum to another is at the heart of these processes, where this is characterized by the dynamics of value and change in the land relations in society. It is these changes that we are witnessing today, that are essential for the sustainable development of the Agribusiness enterprises. In the specialized literature (Soludoc, 2000), these two models for determining ownership are divided into aggressive (revolution) and evolution.

The sustainable development of the company can be measured primarily by the proper management decisions taken, which are the basis of the enterprise development over time. An important part of these decisions is related to the acquisition of rights to the main asset of production, through the purchase or lease. The acquisition of these rights over agricultural land is also considered by scholars (Angelov and Stanimirova, 2000) as a "Subjective right of ownership in a market economy, which consists of three powers, namely: "possession", "use" and "disposal". Each of these rights allows for the implementation of a different strategy for the development of the farm and in each case the decision depends primarily on the financial capabilities of the enterprise and the information available to the company's management.

Another problem in land relations is that agricultural land can only be purchased or lease when we have a well-developed agricultural land market and good enough information availability. In the modern conditions the information network and access to information give very broad information and some scientists (Stanimirova, 2019) share that "The accumulation of the necessary information about the factors affecting the price of agricultural land, trends and prospects for the development of the land market is a prerequisite for an adequate assessment of the so-called "most efficient use of land" and are determining the fair value of land properties". The assessment and the determination of the agricultural land value is an important element of the management decision. This is because the assessment and the value have both accounting impact and directly affect the financial performance and profitability of the enterprises. In modern times, the value of that asset is addreset from (Iliev, $\mathrm{P}$ 2011) as the "monetary equivalent of the value of a real estate at a given point in time in a competitive 
market". This value also strongly affects the partnership relationships of Agricultural enterprises and their counterparties, financing institutions and public authorities. For this, it is essential to take decisions based on information located in the information space. Managers need to divided it generally into the following categories of factors:

Macroeconomic information that gives an insight on the macro framework including the following elements:

- Price of agricultural land and lease at a state level and in the European Union.

- Competitive advantages in the regions and at the state level, such as subsidies, subsidized production of raw materials and materials needed for production.

- Number of agricultural enterprises and structure of the agricultural industry.

- Legal and artificial barriers to the development of competition and the entry of external (international) capital.

- Applied tax and fiscal policy.

- The existence of a competitive capital market and a banking system.

Micro-economic information that gives an overview of the micro framework in the region concerned, including the following factors:

- The price of agricultural land in the area, region and country.

- The cost of agricultural land lease in the area, region and country.

- The number of transactions concluded over the years, whether they are increasing or decreasing.

- The way of permanent use of agricultural land.

- The categories of productive possibilities of soils which are divided on a scale from 1 to 10 .

- The type of buyers and sellers of agricultural land in the region. Whether they are competitor agro enterprises, investment funds, independent investors.

- Whether agricultural land will be used to change status, turning it into urbanized areas or will continue to fulfil its purpose.

- The presence of a large number of agricultural enterprises in the region and increased competition.

- The specifics of the region, what kind of crops are grown - intensive or extensive crops.

- The presence of a large number of owners of agricultural land who process it.

- The availability of natural features such as appropriate climatic conditions, the availability of water sources, the quality of agricultural land and the absence of pollutants.

- Proximity to large settlements, communication such as roads (water and land), electricity, gas is also an important element

In itself, the availability of information on these factors will not give the exact answer and is not a sufficient condition for proper decision-making. The information should be analysed, looked at from a different angle and the quality and comprehensiveness of the factors being analyzed needs to be assessed. In all cases, the individual factors should be dissected and the results must be considered separately and as a whole. The use of a consultant gives a different view and opportunity for a more in-depth analysis of the factors determining the value of the asset in a given period. Regarding to view of group of scientists (Turlakova and Stanimirova, 2006), "In recent years in Bulgaria the importance of consulting in the field of economic and business issues is growing. Unlikely managers do not have such experience as a consultant sensualists in different situations in the public and private sector, in large and small managers organizations, with different clients with different cultures and different business environments - from bureaucratic to innovative. " Decisions on the purchase or lease of agricultural land must be taken on the basis of awareness, analysis and, where appropriate, avoiding decisions based on rumors and emotional purchases.

Another important element for the sustainability of the company is to assess the need to lease or purchase agricultural land. This need must be included in the long-term strategic plans of the 
Agribusiness enterprise and deliver value in a way that does not require the allocation of additional resources. The economic significance of investing in the purchase or lease of agricultural land should meet several basic key requirements, which can be grouped according to the following criteria:

Production conditioning:

- Sufficient proximity of the asset to the main production, which does not entail unnecessary costs for fuels, transport time and depreciation of machinery.

- The asset may be included in the production in such a way as to enable it to be combined with other cultivated agricultural areas.

- Sufficiency of the asset, which allows it to be included in a separate production site.

- Use the asset in the production or ancillary activity. Economic conditioning:

- The asset should be acquired at a value that would allow it to be paid from the production produced by it.

- The paid value should not be above the market value determined at present.

- The asset should be purchased with free cash from the ordinary business of the Agricultural Enterprise and not from the working capital.

- The lease of an asset of agricultural land should be done with working capital. Financial conditioning

- The acquisition of an asset should be done with a long-term borrowed credit resource.

- The lease of an asset should be carried out with working capital financing.

- The price of the capital with which an asset is bought or leased should not be at a price that would turn the investment into a losing investment.

The requirements listed above apply to operating Agricultural Enterprises and do not include start-up companies, where other criteria for economic justification for the purchase or lease of agricultural land should be sought.

\section{Methodology and experimental financial methods to choose one of alternative the purchase or lease of agricultural land.}

In all cases, the purchase or lease of agricultural land is made with capital, which may come from a different source, depending on the stage of development of the company. According to some authors, "Providing the necessary financial resource is a prerequisite for the successful functioning of any business. Unfortunately, the entrepreneurs in the agricultural field still do not have sufficient own funds to finance their activities." This statement is currently valid and is in full force for some groups of Agribusiness enterprises. This group of enterprises represent companies cultivating less than 20 hectares of agricultural land, which lack business formality, financial culture and sufficient collateral. These difficulties continue to have a negative impact on the access to bank financing. According to a study of Fi-compass survey and project calculations from 2019, the lack of investment (long-term) financing in the Agribusiness for Bulgaria is estimated in the range of EUR 157 Mio to EUR 492 Mio, according to Table 1 and two of the methodologies used, as a major part of this financial gap or 76\% (EUR 119.9 Mio and EUR 374 Mio) is concentrated in small companies with arable land below 20 hectares. As can be seen from the attached study, medium and large Agribusiness enterprises do not encounter difficulties in providing capital, and from the calculations made, it is established that the shortage is estimated at 24\% (EUR 117.9 Mio and EUR 38.3 Mio). This percentage, measured through the total bank loan portfolio (EUR 1172 Mio) granted to Agribusiness enterprises, represents between 5 and $10 \%$ and it should be assumed that these are investment intentions, including investments in the purchase of machinery and construction of premises. 
Table 1. Financing gap by farm size in the agriculture sector in 2017, EUR million

\begin{tabular}{|l|l|l|l|l|l|l|}
\hline & & Total & $\begin{array}{c}\text { Short- } \\
\text { term } \\
\text { loans }\end{array}$ & $\begin{array}{c}\text { Medium- } \\
\text { term } \\
\text { loans }\end{array}$ & $\begin{array}{c}\text { Long- } \\
\text { term } \\
\text { loans }\end{array}$ & $\begin{array}{c}\text { Credit } \\
\text { lines/bank } \\
\text { overdrafts }\end{array}$ \\
\hline \multirow{4}{*}{ Upper bound } & Small-sized farms & $\mathbf{6 3 3 . 6}$ & 46.0 & 149.7 & 374.0 & 64.0 \\
\cline { 2 - 8 } & Medium-sized farms & $\mathbf{1 0 2 . 7}$ & 8.8 & 21.6 & 61.5 & 10.7 \\
\cline { 2 - 8 } & Large-sized farms & $\mathbf{1 2 6 . 7}$ & 13.2 & 27.9 & 56.4 & 29.1 \\
\cline { 2 - 8 } & Total & $\mathbf{8 6 3 . 0}$ & $\mathbf{6 8 . 0}$ & $\mathbf{1 9 9 . 1}$ & $\mathbf{4 9 2 . 0}$ & $\mathbf{1 0 3 . 9}$ \\
\hline \multirow{3}{*}{ Lower bound } & Small-sized farms & $\mathbf{2 1 3 . 3}$ & 17.2 & 55.6 & 119.9 & 19.6 \\
\cline { 2 - 8 } & Medium-sized farms & $\mathbf{3 4 . 3}$ & 3.3 & 8.0 & 19.7 & 3.3 \\
\cline { 2 - 8 } & Large-sized farms & $\mathbf{4 2 . 3}$ & 5.0 & 10.4 & 18.1 & 8.9 \\
\cline { 2 - 7 } & Total & $\mathbf{2 8 9 . 0}$ & $\mathbf{2 5 . 5}$ & $\mathbf{7 4 . 0}$ & $\mathbf{1 5 7 . 7}$ & $\mathbf{3 1 . 8}$ \\
\hline
\end{tabular}

The purchase of agricultural land in recent years in Bulgaria has become a good investment for the Agricultural enterprises due to several factors affecting the value of agricultural land and lease, namely:

- The increasing amount of subsidies per hectare area thanks to direct payments and RDPs.

- The consolidation of farmers who are beginning to have easier access to capital.

- The increasing profitability of grain producers due to increased productivity and favorable price levels on the international cereal markets.

- The trend toward decrease in the interest rate levels on the bank loans provided, supporting the demand for agricultural land and increased lease.

The purchase of agricultural land with a bank loan began to make much more serious economic sense than paying a lease, and a large part of the Agribusiness companies started looking for bank financing, preferring to invest bank loan capital in the purchase as an alternative to lease. As can be seen from the Graph 1, the percentage change in the interest rate levels relative to the paid presenting of lease is equalized in 2015, and after this point the acquisition of agricultural land by means of a loan is much more appropriate without including the main factor, the increasing price of agricultural land. Competition in the purchase of agricultural land will continue to intensify due to the current trends of consolidation of companies in the agribusiness sector in Bulgaria and European Union. Small group of large companies will continue to put pressure on the market by purchasing agricultural land suported by their profitability and easy access to financially bank capital. According to the study of the structure of agricultural holdings in 2016, only $3 \%$ from agricultural producers cumulated $70 \%$ from total output in Bulgaria.

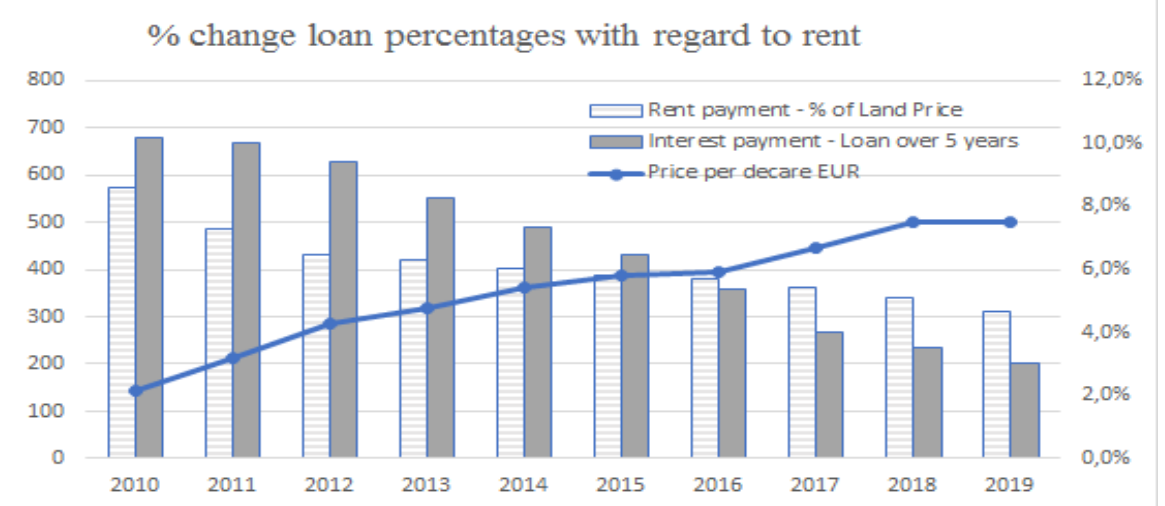

Figure 1. Average $\%$ of leases and price calculated per hectare compered by year land prices 
These three variables have created a phenomenon in the recent years leading to a decrease in the supply of agricultural land, with the price of agricultural land catching up with the average European prices and the lease price approaching some of the highest values in the EU. However, during Eurostat News release from 21 mart 2018 and statistic data by Eurostat, land prices in the European Union remain vary considerably between and within Member States. Not all land is owned by the farmer working the land. Many farmers rent their land, as either a short- or long-term business decision. The cost of renting land is another factor that farmers have to absorb in their business. Mirroring the variation in arable land prices, annual rental prices of one hectare of agricultural land (arable or permanent grassland) also vary starkly between Member States and regions within Member States.

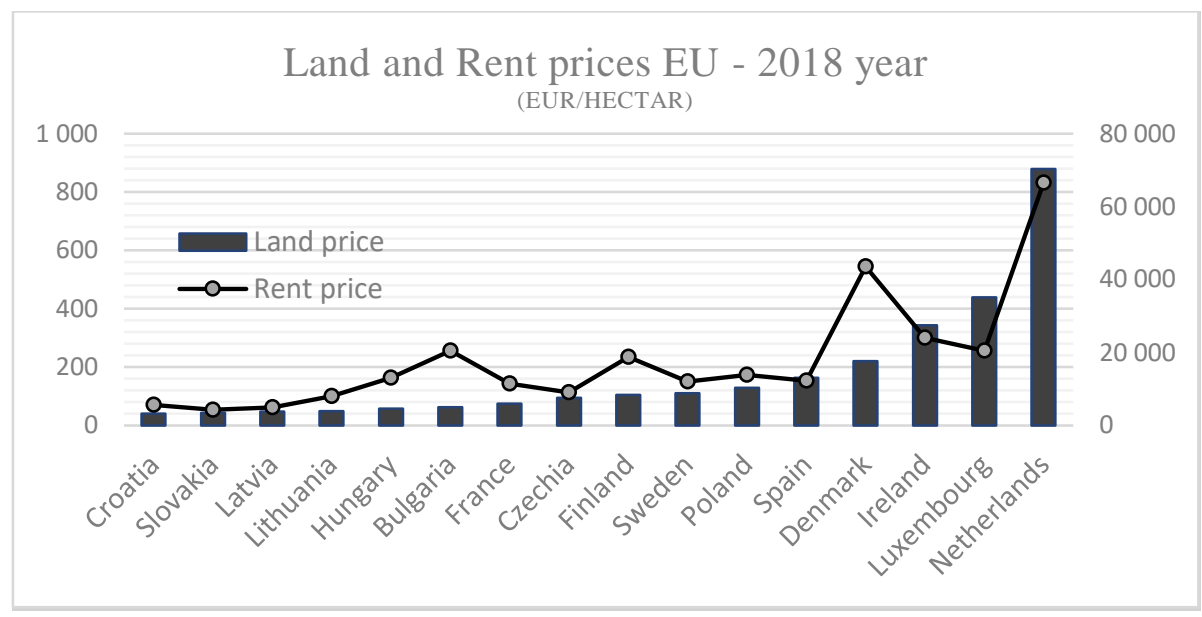

Figure 2. Land and Lease prices EU - 2018 year

As can be seen from the graph, it is clear that the Agribusiness enterprises would have difficulties in several areas while maintaining the trend of high lease price and price per hectare of agricultural land, namely:

- High lease and prices of agricultural land in Bulgaria will continue to be a barrier to the entry of new agricultural enterprises into the sector.

- High leases make Agricultural enterprises very dependent on their own agricultural land.

- The profitability of companies with a larger share of their own agricultural land will make these companies much more competitive than those that do not have their own.

- Agribusiness companies that do not own their own agricultural land will be less profitable in years with poor climatic conditions.

- The purchase of agricultural land with a loan will continue to be economically feasible.

The continued investment in agricultural land by Agricultural enterprises as a result of the above favorable factors confronts businesses with a number of issues related to the value of the lease paid and the price of land. Farmers will increasingly face the dilemma of whether to invest in the purchase of agricultural land, which they will repay in future, or to pay a high price for the right to use the asset.

\section{Results and discussion}

In general, the calculations in this direction show that it should be possible to repay the present value of the money invested over a given period of time. The calculation model will go through the average yield and selling price, considering the future interest payments.

Example: We assume that 5.5 tons of wheat are produced from 1 hectare of agricultural land in a good year. The average price per ton of wheat is around 150 euros per ton. The income of 1 hectare is equal to 995 euros per 1 hectare. Subsidy from the European Union is within 160 levs per hectare. The total income of 1 hectare is 1100 euros. 
The net profit per hectare per year is an average of 250 euros according to expert estimates. The calculations show that the average price of agricultural land is about EUR 5000 per hectare in Bulgaria and the investment can be repaid over a period of 20 years.

Table 2. Historical business model for comparing the acquisition of agricultural land with credit or lease payments

\begin{tabular}{|c|c|c|c|c|c|c|c|c|c|c|}
\hline Years & 2010 & 2011 & 2012 & 2013 & 2014 & 2015 & 2016 & 2017 & 2018 & 2019 \\
\hline Price per hectar EUR & 1395 & 2065 & 2780 & 3105 & 3540 & 3805 & 3850 & 4350 & 4900 & 5265 \\
\hline Rent per hectar EUR & 120 & 150 & 180 & 195 & 213 & 222 & 220 & 235 & 250 & 245 \\
\hline Investmants per 10 he & 13950 & 20650 & 27800 & 31050 & 35400 & 38050 & 38500 & 43500 & 49000 & 52650 \\
\hline Average Interest rate & $10,2 \%$ & $10,0 \%$ & $9,4 \%$ & $8,3 \%$ & $7,3 \%$ & $6,5 \%$ & $5,4 \%$ & $4,0 \%$ & $3,5 \%$ & $3,0 \%$ \\
\hline Interest payments to 2010 & 1423 & 1395 & 1315 & 1154 & 1021 & 905 & 751 & 561 & 494 & 421 \\
\hline Interest payments YoYi(t-1) & 1423 & 1395 & 1947 & 2299 & 2273 & 2297 & 2047 & 1548 & 1540 & 1480 \\
\hline Rent peyment & 1200 & 1500 & 1800 & 1950 & 2134 & 2220 & 2200 & 2350 & 2500 & 2450 \\
\hline
\end{tabular}

In this case, there are basically two alternatives for farmers to finance the purchase of agricultural land - with their own funds and through the use of borrowed bank loan capital. Each of these two options has its advantages and disadvantages. Considering the acquisition of agricultural land with own funds, we should keep in mind that such an investment is limited primarily by two main factors. The accumulated capital from realized profits over the years and by the potential of the company to realize a profit, which will ensure the investment program of the company. An important economic feature is that long-term investments are not to be made with a short-term borrowed capital, i.e. not to direct working capital into investments, which at some point will confront companies with a problem with facilitating the production activity.

A common practice of the Agribusiness enterprises is to finance the purchase of agricultural land with short-term loans, which distorts the balance sheet structure of the enterprises and complicates the process of providing production with the necessary capital. In these cases, commercial financing from suppliers of raw materials is used, as well as pre-sales of products. This indirectly increases the cost of investments and further deteriorates the financial performance of the Agribusiness enterprises, leading to the inability of the company to obtain the best conditions in the process of negotiating terms for commercial and financial transactions.

To finance the investments in agricultural land, the Agribusiness enterprises should adhere to the rule that investments should be made with the available financial resources accumulated from the companies' profits. In this regard, we can derive a formula that shows the company's ability to purchase agricultural land with profits without disrupting and jeopardizing other business processes. The formula shows cumulatively how much agricultural land can be purchased, based on the company's profit per hectare.

$$
\begin{aligned}
& \mathrm{W}=\left(\left(\mathrm{P}^{*} \mathrm{~N}\right) / \mathrm{M}\right)^{*} \mathrm{G}+\mathrm{D} \\
& \mathrm{W}-\text { Possible purchased new hectares } \\
& \mathrm{P}-\text { Total arable land in hectares } \\
& \mathrm{N}-\text { The net profit of the enterprise per hectare } \\
& \mathrm{M}-\text { The price per hectare in the region } \\
& \mathrm{G}-\text { Years to pay off } \\
& \mathrm{D}-\text { Reserves from previous years. }
\end{aligned}
$$

The effect of the investment will be mainly from the saved funds from leases of the newly purchased agricultural land. This effect should be measured and considered as a possible buffer to 
cover other investment costs. The applied model can be upgraded with the growth rate of agricultural land, based on a historical approach. The model in this case would look like this, where:

$$
\begin{aligned}
& \mathrm{L}=(\mathrm{W} * \mathrm{R} 1 * \mathrm{G})^{*} \mathrm{I}^{\wedge} \mathrm{G} \\
& \mathrm{L}-\text { the effect of the investment } \\
& \mathrm{W}-\text { newly purchased agricultural land in hectares } \\
& \mathrm{R} 1 \text { - average lease of arable areas per hectare } \\
& \mathrm{G}-\text { the years of investment } \\
& \mathrm{I}^{\wedge} \mathrm{G} \text { - the effect of the inflation rate. }
\end{aligned}
$$

The application of this approach is suitable for Agribusiness companies, which invest gradually each year in the purchase of small shares, developing extensively without taking additional risks and not using bank loans.

The second option is the purchase of agricultural land with a bank loan, which is applied by Agribusiness enterprises with a strategy for intensive business development. For this option, it should be borne in mind that it is characterized by the payment of interest on the value of the loan and selfparticipation within $20 \%$ of the investment. In this case, the investment can be depreciated over a long period of time, allowing for larger investments in agricultural land. Interest paid on capital should be considered here also as an alternative to the lease paid. In all cases, the repayment of the investment over time has several assumptions, such as the profit per hectare that the investment can bring over time, the amount of the self-participation and the term for which the investment loan will be repaid. The effect of the investment calculated as saved future lease costs may also be included in the calculations when the difference between the estimated interest payments in absolute terms is less than the future lease. The model may also include an expected future increase in the price of purchased agricultural land at a rate of inflation or a rate of historical increase in the price of agricultural land. All other things being equal, where the interest payments equate to lease paid, the profits should not be burdened to the extent that they do not allow other investments or contingencies to be covered.

Measuring the purchase of agricultural land must also go through an assessment of the possibility of the alternative that comes with the lease of agricultural land. Here we must take the disadvantages and advantages provided by leasing agricultural land. Here we must take into account the disadvantages and advantages provided by the leasing of agricultural land. As can be seen from the model, at any time when the price of agricultural land increases, the interest rate compensates for the difference only in cases where it is below 5\%. Currently, in large transactions, some banks offer interest rate hedging tools that allow managers to eliminate one of the unknowns in the equation when buying agricultural land.

However historically, if this rate of increase in the price of agricultural land and lease payments continue in the future, the equalization of the lease payment with the interest paid will takes places not late by the third year at the latest.

\section{Conclusion}

The purchase of agricultural land will continue to be an important factor in the future for the profitability of the Agribusiness enterprises. Making management decisions for leasing, intensive or extensive increase of agricultural land is directly related to the long-term business development strategy. These decisions must be made carefully after analyzing a number of factors that affect the value of the price or lease of agricultural land. Timely decisions, with the proper long-term strategy of the company, allow the business to be much more sustainable over time. The agricultural land will continue to be crucial for the sector and the profitability of each individual company and its role will continue in the future. In conclusion, we should summarize that the purchase of land should not be a 
standalone decision, but should be made on the basis of an economic principle, in a way that ensures the integrity and continuity of the production process.

\section{References}

1. Angelov D., Stanimirova M. (2020); Ikonomicheski aspekti na sobstvenostta varhu zemedelskata zemya v Balgariya, God. UE - Varna, 2000, p.113

2. Soludoc; C.Comparatve institutional development: Lessons from rural Land markets in Africa. World Bank, 2000

3. Stanimirova M; Pazarat na zemedelska zemya v Balgariya - faktori i perspektivi, Natsionalna kragla masa „Ustoychivo upravlenie na pozemlenite resursi - savremenni praktiki i resheniya. UE-Varna, October 2019

4. Iliev, P.; Otsenyavane na nedvizhimi imoti. Izd."Nauka i ikonomika“, IU-Varna, V., 2011, s.38.

5. Turlakova T, Stanimirova M. (2006), Sbornik dokladi ot nauchna konferentsia, Perspektivi za razvitie na biznes konsultantskata deynost v Bulgaria, Univ. izd. Nauka i ikonomika, UE-Varna 2006

6. Special report of European Commission and European investment bank; Financial needs in the agriculture and agri-food sectors in Bulgaria, June 2020,

7. Natsionalen statisticheski institute; Pazar na zemedelskata zemya i rentata v selskoto stopanstvo (2010-2019)

8. Bulgarian National Bank, Statistics on Deposits and Loans by Amount Category and Economic Activity, 2020

9. Eurostat News release 48 from 21 mart 2018; Eurostat data 2020

10. Ministry of Agriculture, Food and Forestry; Farm structure survey in 2016 